\title{
Journal of Transcatheter Interventions
}

e-ISSN e-2595-4350

${ }^{1}$ Casa de Saúde Santa Marcelina, São Paulo, SP, Brazil.
How to cite this article: Matsuda CN, Cade JR, Janella BL, Pazolini VA, Cintra GF, Bourget M, et al. Implementing telemedicine in the initial care for ST-segment elevation myocardial infarction. J Transcat Interven. 2018;26(1):eA0014. https://doi. org/10.31160/JOTCI2018;26(1)A0014

Corresponding author:

Camila Naomi Matsuda

Setor de Hemodinâmica - Térreo

Rua Santa Marcelina, 177 - Vila Carmosina Zip code: 08270-070 - São Paulo, SP - Brazil E-mail: cnmatsuda@yahoo.com.br

Submitted on:

Dec 7, 2017

Accepted on:

Aug 29, 2018

\section{(c) By}

This content is licensed under a Creative Commons Attribution 4.0 International License.

\section{Implementing telemedicine in the initial care for ST-segment elevation myocardial infarction}

\author{
Implementação da telemedicina no atendimento inicial \\ do infarto agudo do miocárdio com supradesnivelamento \\ do segmento ST
}

Camila Naomi Matsuda ${ }^{1}$, Jamil Ribeiro Cade ${ }^{1}$, Bruno Laurenti Janella ${ }^{1}$, Vitor Arantes Pazolini ${ }^{1}$, Guilherme Fernandes Cintra ${ }^{1}$, Monique Bourget ${ }^{1}$, Marco Antônio Perin ${ }^{1}$

\section{DOI: 10.31160/JOTCI2018;26(1)A0014}

ABSTRACT - Background: In ST-segment elevation myocardial infarction, the need for early recanalization of the culprit artery, associated to the difficult access of the general population to medical services that provide such treatment, contribute to increased mortality in such patients. This is the rationale for implementing the LATIN project, acronym for Latin America Telemedicine Infarct Network, in areas characterized by high demographic density and difficult access to healthcare services. The objective of the present study was to analyze the first year results of this project. Methods: The sample included six centers with telemedicine systems participating in the LATIN registry. In cases of acute myocardial infarction, the electrocardiogram and clinical summary were sent to the mobile phones of the interventional cardiologists at the reference hospital. Clinical and angiographic characteristics, intervals between care delivered and hospital outcomes were analyzed. Results: From June 2014 to June 2015, a total of 125 patients were enrolled, mean age of $58.3 \pm 11.1$ years, $66.4 \%$ males, $30.4 \%$ suffering from diabetes mellitus and $28.8 \%$ smokers. A total of 85 primary percutaneous coronary interventions were performed with a mean door-to-balloon time of $46.4 \pm 25.0$ minutes. The pharmaco-invasive strategy was adopted in $20.0 \%$ of patients. In-hospital mortality was $5.6 \%$. Conclusions: The telemedicine system was a valuable partner in early diagnosis and rapid initiation of the gold standard treatment for acute myocardial infarction in the region analyzed, with possible impact in survival, cost reduction and morbimortality.

Keywords: Myocardial infarction; Telemedicine; Angioplasty; Time-to-treatment

RESUMO - Introdução: No infarto agudo do miocárdio com supradesnivelamento do segmento ST, a necessidade de recanalização precoce da artéria culpada, associada às dificuldades de acesso da população em geral aos serviços médicos que realizam esta modalidade de tratamento, contribui para o aumento da mortalidade nesse perfil de paciente. Diante do exposto, encontra-se o racional de implementação do projeto denominado LATIN, acrônimo para Latin America Telemedicine Infarct Network, em áreas caracterizadas por concentração demográfica densa e dificuldades de acesso à saúde. O objetivo do presente estudo foi analisar os resultados do primeiro ano deste projeto. Métodos: A amostra compreendeu seis centros dotados de telemedicina participantes do registro LATIN. Nos casos de infarto agudo do miocárdio, eletrocardiograma e resumo clínico eram encaminhados por mensagem para os celulares dos cardiologistas intervencionistas do hospital de referência. Foram analisadas as características clínicas, angiográficas, os intervalos de atendimento e os desfechos hospitalares. Resultados: De junho de 2014 a junho de 2015, foram incluídos 125 pacientes, com média de idade de $58,3 \pm 11,1$ anos, $66,4 \%$ do sexo masculino, $30,4 \%$ portadores de diabetes melito e $28,8 \%$ tabagistas. Foram realizadas 85 intervenções coronárias percutâneas primárias, com tempo porta-balão médio de 46,4 $\pm 25,0$ minutos. A estratégia fármaco-invasiva foi realizada em $20,0 \%$ dos pacientes. A mortalidade hospitalar foi de $5,6 \%$. Conclusões: O sistema de telemedicina foi um aliado valioso no diagnóstico precoce e na rápida instituição do padrão-ouro de tratamento do infarto agudo do miocárdio na região analisada, com possível impacto na sobrevida, na redução dos custos e na morbimortalidade.

Palavras-chave: Infarto do miocárdio; Telemedicina; Angioplastia; Tempo para o tratamento 


\section{INTRODUCTION}

In the United States, cardiovascular disease is estimated to kill 2,160 people per day. Among the deaths due to acute coronary syndrome, approximately $70 \%$ of them occur outside the hospital environment, resulting in an serious health problem. ${ }^{1,2}$ Despite the considerable progress in the treatment of ST-segment elevation myocardial infarction (STEMI) and ischemic coronary diseases in the last decades, with a significant reduction in mortality rates, ${ }^{3,4}$ there are still areas lacking in adequate health care services, such as rural areas and working class suburbs of large urban centers, where these benefits are not achieved. ${ }^{5,6}$ Therefore, lower mortality rates from STEMI are more pronounced in developed countries, among the population with higher schooling and income, especially due to timely access to adequate diagnosis and treatment, myocardial reperfusion by primary percutaneous coronary intervention (PCI) or fibrinolysis, access to dual antiplatelet therapy and hospitalization in coronary units. ${ }^{7-9}$

In Brazil, cardiovascular diseases are the leading cause of proportional mortality, accounting for $29 \%$ of deaths in 2010, which translates to approximately 53.8 deaths per 100 thousand inhabitants, greatly affecting the most productive age group in the country (30 to 69 years). ${ }^{10-12}$ It is also estimated that ischemic heart disease accounted for 83 thousand deaths in 2014, 46.27\% of which in the Southeast Region, ranking STEMI as the second most frequent cause of death, with high in-hospital mortality rates in the public health system, corresponding on average to $16.2 \%$ in $2000,16.1 \%$ in 2005 , and $15.3 \%$ in $2010 .{ }^{13}$ These statistics are attributed to difficulties in early diagnosis, and lack of patient access to myocardial reperfusion, intensive care and/or coronary care units, and the recommended therapeutic measures. ${ }^{14}$

The pathophysiological mechanism of STEMI is thrombus occlusion of one of the coronary arteries, with progressive functional loss of myocytes in the occluded artery-related topography. The mortality risk in the first year increases by $7.5 \%$ every 30 minutes of delayed recanalization of the vessel. ${ }^{8}$ Therefore, early reperfusion is the primary goal in the treatment of STEMI, which resulted in the current target of 60 minutes between the arrival of the patient at the hospital and the opening of the culprit artery. ${ }^{9}$ For this reason, several efforts are underway to triage, diagnose and transfer these patients to hospitals that have an interventional cardiology service with professionals experienced in implementing primary PCI. ${ }^{6}$

Among these measures, a strategy for optimizing care for STEMI patient is implemented in places with limited resources, using 12-lead ECGs, connected via internet to a central office, where trained physicians analyze the ECG for an earlier diagnosis of STEMI, and direct the removal of these patients to a hospital with a catheterization laboratory (cath lab).
Mehta et al. compared the implementation of this strategy, called Latin America Telemedicine Infarct Network (LATIN), in Colombia, observing a significant reduction of disparities in STEMI care between developed and developing countries. This finding is directly associated with the reduction in the time interval to perform and adequately interpret the ECG, with an early referral to primary PCI or thrombolysis. ${ }^{15}$ In Brazil, Solla et al. reported the first experience with this strategy, proving it to be feasible and with good outcomes, comparable to those in developed countries. ${ }^{16-18}$

Difficulties faced by the population in accessing tertiary care facilities with primary PCI or healthcare services capable of diagnosing STEMI, associated to the remoteness of the hospital Casa de Saúde Santa Marcelina (CSSM) location, were the rationale for implementing a LATIN pilot project on the outskirts of the eastern part of the city of São Paulo (SP), encompassing more than 5 million inhabitants.

The primary objective of the present study was to describe the implementation of the project, the flowchart for the removal of the STEMI patient, and the analysis of the first 125 patients after the first year of its opening. As a secondary objective, we analyzed the map of the eastern zone of São Paulo, the distance traveled to the CSSM, as well as the transport time from the primary service units to the CSSM, the door-to-balloon time, the first-medicalcontact-to-balloon time, the angiographic outcomes, and the in-hospital clinical outcomes.

\section{METHODS}

This was a descriptive study, with retrospective implementation and flowchart data collection of the LATIN-CSSM project (https://santamarcelina.org/hospital/telemedicina), from June 2014 to June 2015. The primary care units located on the outskirts were called spokes, and the highcomplexity central hospital (CSSM) was called hub. The spoke-hub transfer time and the hub-door-to-balloon time, as well as the in-hospital outcomes, were analyzed in terms of major adverse cardiac and cerebrovascular events. This study was approved by the Ethics and Research Committee of Hospital Santa Marcelina (CAAE: 67353517.7.0000.0066).

\section{Implementation of the program}

The program involves a trained multidisciplinary team, in the units participating in the project (spokes), equipped with 12-lead ECG devices connected to a telemedicine center. The program steps includes the patient's reception (immediate triage), and the professionals who perform the 12-lead ECG and send it online to the team of trained physicians at International Telemedical Systems (ITMS) located in Uberlândia (MG), Brazil.

Patients diagnosed with STEMI receive, unless contraindicated, 300mg of aspirin and 600mg of clopidogrel, 
as well as coronary vasodilators (intravenous nitroglycerin) and, if necessary, analgesia with opioids and oxygen.

The patients are transported immediately, by an ambulance with a physician on board, to the cath lab at the CSSM. In the case of STEMI, the telemedicine company itself sends a cellphone message to the interventional cardiologist on call, communicating the diagnosis, and by email, a brief clinical summary and the ECG interpretation. Figure 1 shows the spoke activation flowchart, with the interface among ITMS, the transport team and the cath lab team, in case of a STEMI diagnosis.

\section{Mapping of the spokes}

At the time of this study, there were six centers equipped with 12-lead ECG devices (Table 1), connected to the telemedicine system, trained in chest pain patient care, with immediate triage, and electrocardiographic analysis and interpretation in less than 10 minutes. The centers that deliver care to patients are trained by the LATIN medical team, and monthly meetings are conducted to evaluate the program and minimize possible doubts about the project. Figure 2 shows, in São Paulo map, the distances between the spokes and the CSSM.

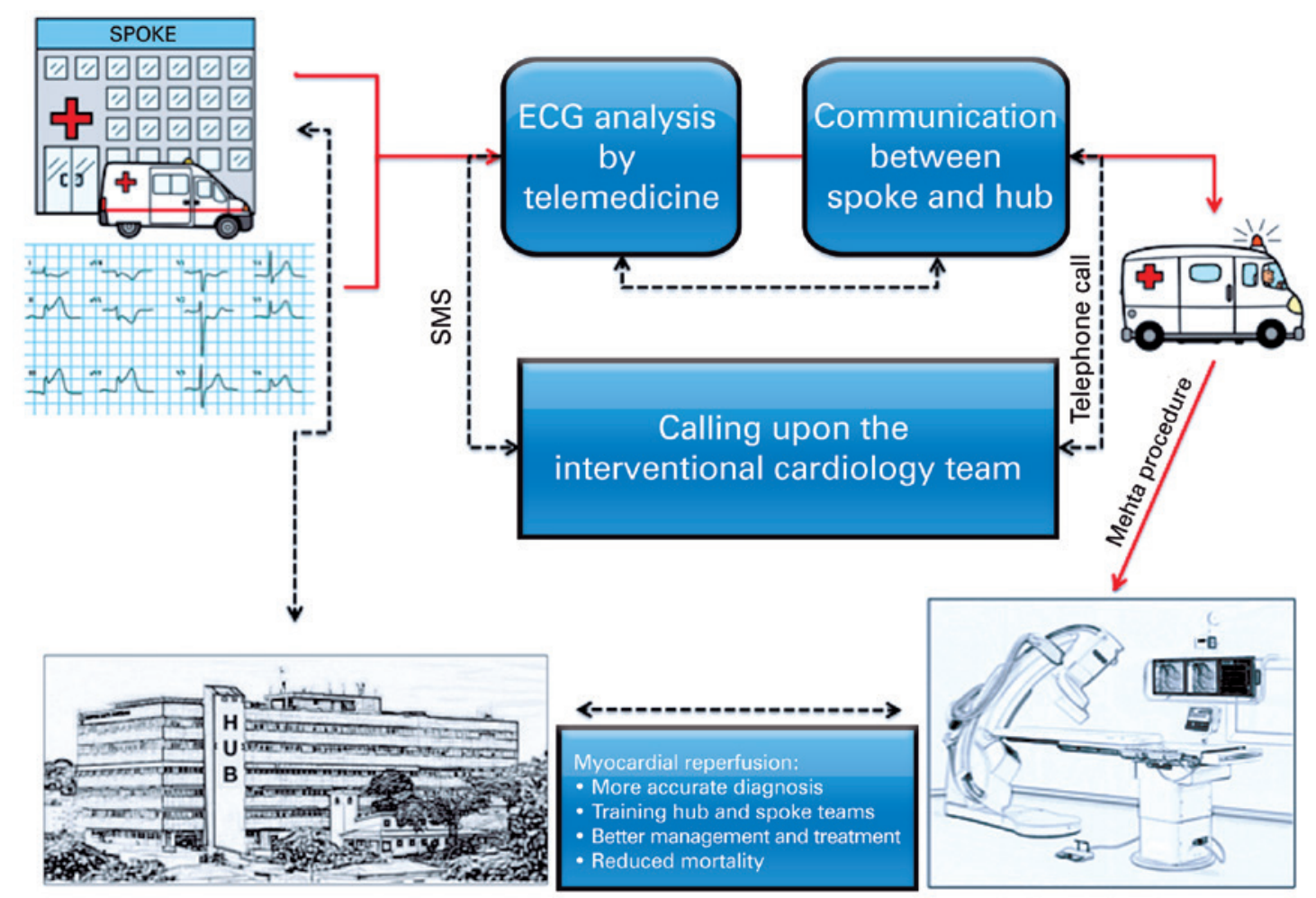

Figure 1. Activation flowchart of the Latin America Telemedicine Infarct Network (LATIN). The electrocardiogram is interpreted by the International Telemedical Systems (ITMS), which communicates it to the health center where the patient is (spoke), to the transport team, and to the Interventional Cardiology team (hub). Mehta procedure: the patient is admitted directly to the cath lab, without passing through the emergency room.

Table 1. Participating centers and mean distance to tertiary care service (in kilometers)

\begin{tabular}{lc}
\hline Medical centers (spokes) & Kilometers \\
\hline Pronto-Socorro Municipal Júlio Tupy (spoke 1) & 10.0 \\
\hline Hospital Municipal Cidade Tiradentes (spoke 2) & 12.5 \\
\hline AMA Santa Marcelina (spoke 3) & 0.6 \\
\hline Hospital Geral - Unidade Itaim Paulista (spoke 4) & 15.0 \\
Pronto Atendimento Dr. Atualpa Girão Rabelo (spoke 5) & 12.0 \\
\hline Hospital Geral de Itaquaquecetuba (spoke 6) & 20.8 \\
\hline Mean distance between spokes and Casa de Saúde Santa Marcelina (mean \pm standard deviation) & $11.8 \pm 6.6$ \\
\hline
\end{tabular}




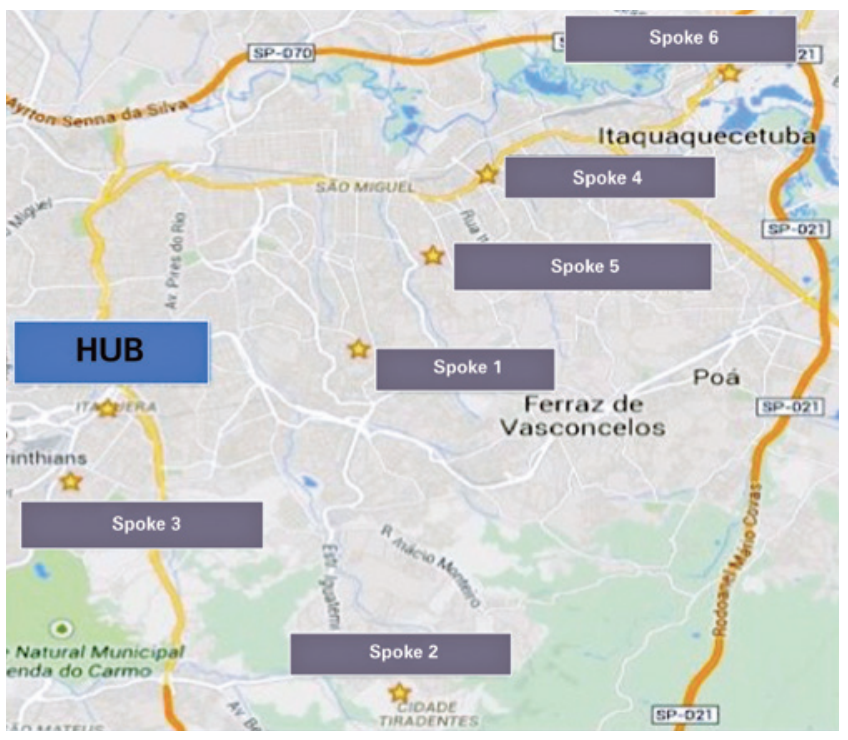

Figure 2. Map of the Eastern zone of São Paulo with the centers participating (spokes) and their geographic position in relation to the hub. Source https://www.google.com.br/maps

\section{Statistical analysis}

Categorical variables were expressed as absolute numbers and percentages. Continuous variables were expressed as mean \pm standard deviation or interquartile range, depending on the type of distribution. We used the Shapiro-Wilks test to evaluate the normal distribution. A p-value of $<0.05$ was considered significant, calculated by the statistical software R (R Development Core Team 2008).

\section{RESULTS}

The program started in June 2014. A total of 22,177 ECGs were generated by June 2015, all of which were analyzed by ITMS. The diagnosis of STEMI was confirmed in 125 $(0.56 \%)$ patients, with mean age of $58.3 \pm 11.1$ years, and $66.4 \%$ of males. Diabetes mellitus was present in $30.4 \%$ of patients, hypertension in $60.0 \%$, and active smoking in $28.8 \%$. There were 25 (20.0\%) cases in which thrombolytic therapy was indicated due to the unavailability of an ambulance to transport the patients to the hub, and coronary angiography was scheduled later. Of the universe of patients with thrombolysis, ten were excluded due to lack of data on health care indicators. The mean spoke-needle time was $71.0 \pm 48.0$ (16-207) minutes.

In eight (6.4\%) patients, the case was discussed with the interventional cardiology team, and an elective coronary angiography was the procedure chosen due to the diagnosis of myocardial infarction (more than 12 hours after the onset of symptoms), without criteria for performing an emergency procedure. Exclusively medical therapy was indicated in seven (5.6\%) patients. Surgical myocardial revascularization was indicated in nine $(7.2 \%)$ patients, due to multivessel coronary disease, without refractory ischemia, at the time of coronary angiography (Figure 3).

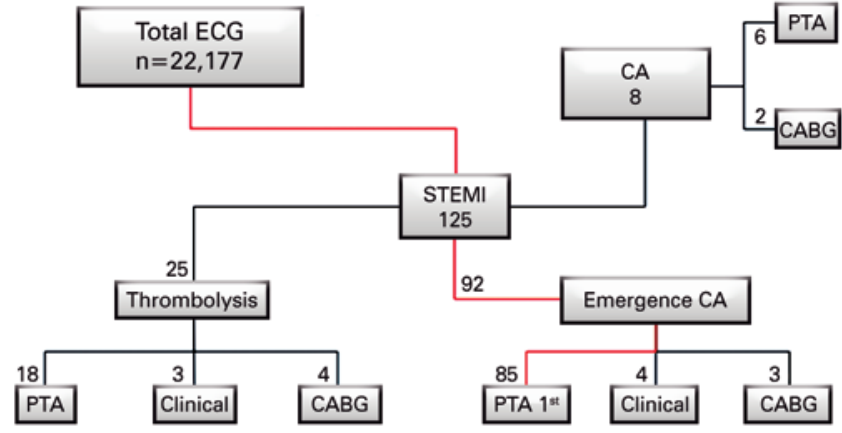

Figure 3. Sample universe. ECG: electrocardiogram; STEMI: ST-segment elevation myocardial infarction; CA: coronary angiography; PTA: percutaneous transluminal angioplasty; CABG: coronary artery bypass graft.

In-hospital mortality was $5.6 \%(n=7)$, four of which were due to cardiac causes (one cardiogenic shock, two sudden deaths 12 hours after primary PCI, and one recurrent myocardial infarction). Non-cardiovascular causes included septic shock (one case), ovarian neoplasm (one case), and pulmonary thromboembolism (one case).

Primary PCI was performed in $85(68.0 \%)$ patients, with angiographic success in $96.5 \%$ of cases (Table 2 ). The

Table 2. Clinical, angiographic and primary percutaneous coronary intervention procedures characteristics

\begin{tabular}{|lc}
\hline Variables & \\
\hline Age, years & $58.3( \pm 11.3)$ \\
\hline Male & $26(30.0)$ \\
\hline Diabetes mellitus & $30(35.3)$ \\
\hline Active smoking & $55(64.7)$ \\
\hline Hypertension & \\
\hline Culprit coronary artery & $48(56.5)$ \\
\hline LAD & $30(35.3)$ \\
\hline RCA & $6(7.0)$ \\
\hline LCX & $1(1.2)$ \\
\hline SVG & \\
\hline TIMI pre-PCI & $58(68.2)$ \\
\hline 0 & $8(9.4)$ \\
\hline 1 & $8(9.4)$ \\
\hline 2 & $11(13.0)$ \\
\hline 3 & \\
\hline TIMI post-PCI & $3(3.5)$ \\
\hline 2 & $82(96.5)$ \\
\hline 3 & $34(40.0)$ \\
\hline Radial approach & $51(60.0)$ \\
\hline Femoral approach & $82(96.5)$ \\
\hline Angiographic success & \\
\hline R & \\
\hline
\end{tabular}

Results expressed as mean \pm standard deviation or $n$ (\%). LAD: left anterior descending artery; RCA: right coronary artery; LCX: left circumflex; SVG: saphenous vein graft bypass; TIMI: Thrombolysis in Myocardial Infarction; PCl: percutaneous coronary intervention. 
mean time between identification of STEMI and transfer to the hub (spoke-hub) was $78.0 \pm 38.0$ (21-260) minutes. The mean time between arrival at the hub and coronary recanalization (door-to-balloon time) was $46.4 \pm 25.0 \mathrm{mi}-$ nutes. The mean first-medical-contact-to-balloon time was $124.4 \pm 39.8$ minutes, and 44 patients $(51.8 \%)$ had an interval of less than 120 minutes (Table 3 ).

Table 3. In-hospital adverse outcomes and spoke-hub and doorto-balloon times of patients submitted to primary percutaneous coronary intervention

\begin{tabular}{lc}
\hline Variables & \\
\hline Mortality & $6(7.0)$ \\
Stroke & $0(0.0)$ \\
Spoke-Casa de Saúde Santa Marcelina time, minutes & $78.0 \pm 38.0$ \\
First medical contact-balloon, minutes & $124.4 \pm 39.8$ \\
Casa de Saúde Santa Marcelina door-to-balloon time, minutes & $46.4 \pm 25.0$ \\
\hline Results expressed as n (\%) or mean \pm standard deviation.
\end{tabular}

\section{DISCUSSION}

The implementation of an agile chest pain patient care system with a 12-lead ECG performed in the first 10 minutes of admission, connected via internet to a center with trained physicians who evaluate the presence of ST-segment elevation, myocardial infarction, offers the possibility of an early diagnosis, an initial direction for immediate removal of the patient to of a referenced tertiary center equipped with a cath lab, or initiation a fibrinolytic therapy adequate to remote places without a full-time cardiologist. ${ }^{15,17,19}$

Sejersten et al. ${ }^{20}$ suggested that a telemedicine service can increase the number of STEMI diagnoses, enabling appropriate treatment of the patients, and reducing the discrepancies among the diverse realities of the different services. ${ }^{15}$ This is a positive aspect of public health care, with possible cost reduction, considering that early coronary reperfusion reduces the extent of myocardial damage, preserving the overall ventricular function - although a cost-effectiveness analysis was not in the scope of our study.

LATIN is a pioneering project in the city of São Paulo, and its main objective is to perform primary $\mathrm{PCI}$, differing from the program of the Universidade Federal de São Paulo (UNIFESP), in which out-of-hospital thrombolysis is the main focus. The promising outcomes support the feasibility of both systems. ${ }^{21}$ Other determining factors for the success of the program, already contemplated by a guideline dedicated to the topic, are early diagnosis and immediate transportation to the referral hospital for interventional cardiology. In our series, a transfer delay $(78.0 \pm 38.0 \mathrm{minu}-$ tes) was observed, and the difficulty to optimize immediate transport is the preponderant factor. It is speculated that the use of an exclusive ambulance for the transportation of these patients could reduce this interval, and currently, each center has one single ambulance for general use.
The mean first medical contact-to-balloon time exceeded the norm recommended by approximately 5 minutes, whereas patients undergoing thrombolysis in different spokes showed door-to-needle times that are in keeping with current recommendations. Regarding the door-toballoon time in the hub, we observed a mean value of only $46.4 \pm 25.0$ minutes, probably because the interventional cardiologists received telephone confirmation of STEMI on the way, which possibly resulted in an earlier vessel opening and, consequently, a better prognosis. ${ }^{22}$

The direct transportation of patients with pre-hospital diagnosis of STEMI to the cath lab, preceded by contact and activation of the team, a characteristic observed in the flowchart of the analyzed program, is an effective measure that increases the percentage of patients with door-toballoon time lower than 60 minutes, which translates into higher final Thrombolysis in Myocardial Infarction (TIMI) grade 3 flow rates, improvement of myocardial reperfusion markers, shorter time to reperfusion, and, consequently, decreased mortality rate. ${ }^{23-25}$

All-cause mortality in the in-hospital phase of the full sample (125 patients) was $5.6 \%$, which is impactful when compared to that found in previous records - about $15 \%$. Mortality due to STEMI is consistent with previously published series, ranging from $7.0 \%$ to $18.0 \%$, and lower than the mortality rate recorded in the Department of Information Technology of the Unified Health System (DATASUS) in 2010, which was $15.3 \% .{ }^{8}$ We attributed the observed reduction in this important indicator to the use of the LATIN program.

\section{CONCLUSION}

We reported the first project implemented in the city of São Paulo involving medical centers equipped with a telemedicine system in health care sectors lacking in adequate cardiology services. In addition to offering early diagnosis, initial treatment and rapid transportation, we observed an adequate door-to-balloon time, with low inhospital mortality.

The LATIN project enables health care in economically underprivileged areas, using an appropriate flowchart, with possible impact on cost reduction, morbidity reduction, and long-term survival increase.

\section{REFERENCES}

1. Movahed MR, John J, Hashemzadeh M, Hashemzadeh M. Mortality trends for non-ST-segment elevation myocardial infarction (NSTEMI) in the United States from 1988 to 2004 Clin Cardiol. 2011;34(11):689-92.

2. Schmidt M, Jacobsen JB, Lash TL, Bøtker HE, Sørensen HT. 25 year trends in first time hospitalisation for acute myocardial infarction, subsequent short and long term mortality, and the prognostic impact of sex and comorbidity: a Danish nationwide cohort study. BMJ. 2012;344;2:e356. 
3. Moran A, Odden MC. Trends in myocardial infarction mortality in Spain and the United States: a downhill or uphill race in the twenty-first century? Rev Esp Cardiol (Engl Ed). 2012;65(12): 1069-71.

4. Ford ES, Ajani UA, Croft JB, Critchley JA, Labarthe DR, Kottke TE, et al. Explaining the decrease in U.S. deaths from coronary disease, 1980-2000. N Engl J Med. 2007;356(23):2388-98.

5. Alexander T, Mehta S, Mullasari A, Nallamothu BK. Systems of care for ST-elevation myocardial infarction in India. Heart. 2012;98(1):15-7.

6. Kaifoszova Z, Kala P, Alexander T, Zhang Y, Huo Y, Snyders A, et al. Stent for Life Initiative: leading example in building STEMI systems of care in emerging countries. EuroIntervention. 2014; 10 Suppl T:T87-95. https://doi.org/10.4244/EIJV10STA14

7. Floyd KC, Yarzebski J, Spencer FA, Lessard D, Dalen JE, Alpert JS, et al. A 30-year perspective (1975-2005) into the changing landscape of patients hospitalized with initial acute myocardial infarction: Worcester Heart Attack Study. Circ Cardiovasc Qual Outcomes. 2009;2(2):88-95.

8. O'Gara PT, Kushner FG, Ascheim DD, Casey DE Jr, Chung MK, de Lemos JA, Ettinger SM, Fang JC, Fesmire FM, Franklin BA, Granger CB, Krumholz HM, Linderbaum JA, Morrow DA, Newby LK, Ornato JP, Ou N, Radford MJ, Tamis-Holland JE, Tommaso CL, Tracy CM, Woo YJ, Zhao DX, Anderson JL, Jacobs AK, Halperin JL, Albert NM, Brindis RG, Creager MA, DeMets D, Guyton RA, Hochman JS, Kovacs RJ, Kushner FG, Ohman EM, Stevenson WG, Yancy CW; American College of Cardiology Foundation/American Heart Association Task Force on Practice Guidelines. 2013 ACCF/ AHA guideline for the management of ST-elevation myocardial infarction: a report of the American College of Cardiology Foundation/American Heart Association Task Force on Practice Guidelines. Circulation. 2013;127(4):e362-425.

9. Task Force members, Windecker S, Kolh P, Alfonso F, Collet JP, Cremer J, Falk V, Filippatos G, Hamm C, Head SJ, Jüni P, Kappetein AP, Kastrati A, Knuuti J, Landmesser U, Laufer G, Neumann FJ, Richter DJ, Schauerte P, Sousa Uva M, Stefanini GG, Taggart DP, Torracca L, Valgimigli M, Wijns W, Witkowski A. 2014 ESC/EACTS Guidelines on myocardial revascularization: The Task Force on Myocardial Revascularization of the European Society of Cardiology (ESC) and the European Association for CardioThoracic Surgery (EACTS) Developed with the special contribution of the European Association of Percutaneous Cardiovascular Interventions (EAPCI). Eur Heart J. 2014;35(37):2541-619.

10. Pereira JC, Barreto SM, Passos VM. [Cardiovascular risk profile and health self-evaluation in Brazil: a population-based study]. Rev Panam Salud Publica. 2009 ;25(6):491-8. Portuguese.

11. Mansur AP, Favarato D. Mortality due to cardiovascular diseases in Brazil and in the metropolitan region of São Paulo: a 2011 update. Arq Bras Cardiol. 2012;99(2):755-61.

12. Brasil. Ministério da Saúde. Rede Interagencial de Informação para a Saúde. Taxa de mortalidade específica por doenças do aparelho circulatório [Internet]. Brasília (DF): RIPSA; 2012 [citado 2017 Jan 31]. Disponível em: http://tabnet.datasus.gov. br/cgi/tabcgi.exe?idb2012/c08.def

13. Brasil. Ministério da Saúde. Rede Interagencial de Informação para a Saúde. Taxa de mortalidade específica por doenças do aparelho circulatório [Internet]. Brasília (DF): RIPSA; 2014. [citado 2017 Jan 31]. Disponível em: http://tabnet.datasus.gov.br/cgi/ tabcgi.exe?idb2014/c08.def
14. Ribeiro AL. The two Brazils and the treatment of acute myocardial infarction. Arq Bras Cardiol. 2009;93(2):83-4.

15. Mehta S, Botelho R, Rodriguez D, Fernández FJ, Ossa MM, Zhang T, et al. A tale of two cities: STEMI interventions in developed and developing countries and the potential of telemedicine to reduce disparities in care. J Interv Cardiol. 2014;27(2):155-66.

16. Solla DJ, Paiva Filho IM, Delisle JE, Braga AA, Moura JB, Moraes $\mathrm{X} \mathrm{Jr}$, et al. Integrated regional networks for ST-segment-elevation myocardial infarction care in developing countries: the experience of Salvador, Bahia, Brazil. Circ Cardiovasc Qual Outcomes. 2013; 6(1):9-17.

17. Clemmensen P, Schoos MM, Lindholm MG, Rasmussen LS, Steinmetz J, Hesselfeldt R, et al. Pre-hospital diagnosis and transfer of patients with acute myocardial infarction-a decade long experience from one of Europe's largest STEMI networks. J Electrocardiol. 2013;46(6):546-52.

18. Terkelsen CJ, Nørgaard BL, Lassen JF, Gerdes JC, Ankersen JP, Rømer F, et al. Telemedicine used for remote prehospital diagnosing in patients suspected of acute myocardial infarction. J Intern Med. 2002;252(5):412-20.

19. Ibanez B, James S, Agewall S, Antunes MJ, Bucciarelli-Ducci C, Bueno H, Caforio ALP, Crea F, Goudevenos JA, Halvorsen S, Hindricks G, Kastrati A, Lenzen MJ, Prescott E, Roffi M, Valgimigli M, Varenhorst C, Vranckx P, Widimský P; ESC Scientific Document Group. 2017 ESC Guidelines for the management of acute myocardial infarction in patients presenting with STsegment elevation: the Task Force for the management of acute myocardial infarction in patients presenting with ST-segment elevation of the European Society of Cardiology (ESC). Eur Heart J. 2018;39(2):119-77.

20. Sejersten M, Sillesen M, Hansen PR, Nielsen SL, Nielsen H, Trautner S, et al. Effect on treatment delay of prehospital teletransmission of 12-lead electrocardiogram to a cardiologist for immediate triage and direct referral of patients with ST-segment elevation acute myocardial infarction to primary percutaneous coronary intervention. Am J Cardiol. 2008;101(7):941-6.

21. Ferreira G, Moraes PI, Jesus EV, Gonçalves Júnior, Alves CM, Caixeta A, et al. ST segment elevation myocardial infarction (STEMI) network sustains low hospital mortality throughout the years in an emerging country location. Congress, 2014. Barcelona, Spain. Oxford Univ. Press Great Clarendon st, Oxford OX2 6DP, England.

22. Oliveira MT Junior, Canesin MF, Marcolino MS, Ribeiro AL, Carvalho AC, Reddy S, et al. Diretriz de Telecardiologia no Cuidado de Pacientes com Síndrome Coronariana Aguda e Outras Doenças Cardíacas. Arq Bras Cardiol. 2015;104(5):1-26.

23. Dieker HJ, Liem SS, El Aidi H, van Grunsven P, Aengevaeren WR, Brouwer MA, et al. Pre-hospital triage for primary angioplasty: direct referral to the intervention center versus interhospital transport. JACC Cardiovasc Interv. 2010;3(7):705-11.

24. Andrade PB, Tebet MA, Nogueira EF, Rinaldi FS, Esteves VC, Andrade MV, et al. Impact of inter-hospital transfer on the outcomes of primary percutaneous coronary intervention. Rev Bras Cardiol Invasiva. 2012;20(4):361-6.

25. Le May MR, Wells GA, So DY, Glover CA, Froeschl M, Maloney J, et al. Reduction in mortality as a result of direct transport from the field to a receiving center for primary percutaneous coronary intervention. J Am Coll Cardiol. 2012;60(14):1223-30. 